\title{
Peran Lembaga Pemasyarakatan Kelas II A Watampone Dalam Pembinaan Narapidana Penyalahgunaan Narkoba Berdasarkan Undang-Undang Nomor 12 Tahun 1995 tentang Pemasyarakatan
}

\author{
Jumarni \\ Institut Agama Islam Negeri (IAIN) Bone \\ Jumarniiainbone1997@gmail.com
}

\begin{abstract}
Abstrak
Tujuan dari penelitian ini adalah (1) Untuk mengetahuiPeran Lembaga Pemasyarakatan Kelas II A Watampone dalam melakukan pembinaan narapidana penyalahgunaan narkoba berdasarkan Undang-Undang Nomor 12 Tahun 1995 tentang Pemasyarakatan; (2) Untuk mengetahui hambatan-hambatan Lembaga Pemasyarakatan Kelas II A Watampone dalam melakukan pembinaan narapidana penyalahgunaan narkoba berdasarkan Undang-Undang Nomor 12 Tahun 1995 tentang Pemasyarakatan.Metode yang digunakan dalam penelitian ini adalah penelitian lapangan dengan pendekatan yuridis empiris yang menggunakan sumber data primer dan sumber data skunder yang terdiri dari bahan hukum primer, bahan hukum skunder dan bahan hukum tersier. Adapun teknik pengumpulan data yakni dengan cara melakukan wawancara dan melakukan studi dokumen kepustakaan yang erat kaitannya dengan objek yang diteliti, kemudian dianalisis dengan cara kualitatif dengan menggunakan teknik pengolahan data yakni reduksi data, penyajian data dan penarikan kesimpulan. Hasil penelitian ini menunjukkan bahwa peran Lembaga Pemasyarakatan Kelas II A Watampone telah dilaksanakan sesuai dengan UndangUndang Nomor 12 Tahun 1995 tentang Pemasyarakatan namun belum optimal karena kurangnya pengetahuan petugas dalam melakukan pembinaan dan masih adanya narapidana narkoba yang berstatus residivis.Adapun hambatan yang dihadapi oleh Lembaga Pemasyarakatan Kelas II A Watampone dalam melakukan pembinaan narapidana peyalahgunaan narkoba yakni kurangya sumberdaya manusia, kurangnya sarana dan prasarana, dan kurangnya dana.
\end{abstract}

\section{Kata Kunci: Peran Lembaga Pemasyarakatan, Pembinaan Narapidana Penyalahgunaan Narkoba Berdasarkan Undang-Undang Nomor 12 Tahun 1995 tentang Pemasyarakatan}


74 | Jumarni

\section{PENDAHULUAN}

Pembinaan narapidana yang dilakukan di lembaga pemasyarakatan ditujukan agar selama pembinaan dan sudah selesai menjalankan pidananya para narapidana dapat berhasil memantapkan kembali harga diri dan kepercayaan dirinya serta bersikap optimis akan masa depannya, dapat memperoleh pengetahuan, minimal keterampilan untuk bekal mampu hidup mandiri dan berpartisipasi dalam kegiatan pembangunan nasional, berhasil menjadi manusia yang patuh hukum yang tercermin pada sikap dan perilaku yang tertib, disiplin serta mampu menggalang rasa kesetiakawanan nasional dan memiliki jiwa semangat pengabdian terhadap bangsa dan negara.

Pembinaan narapidana tidak dapat hanya dilakukan oleh petugas pemasyarakatan saja tetapi sangat diperlukan bantuan dari berbagai pihak yang terlibat dalam pembinaan narapidana. Harus disadari bahwa dalam pembinaan narapidana prinsip-prinsip dasar pembinaan harus berjalan seiring, searah dan selaras untuk mencapai tujuan. ${ }^{105}$

Prinsip itu adalah kemauan atau hasrat narapidana untuk membina sendiri, keterlibatan keluarga dalam membina anggota keluarganya yang menjadi narapidana dan keterlibatan masyarakat unruk ikut serta pemerintah dalam membina narapidana. hanya dengan peran serta semua pihak, pembinaan narapidana dapat dicapai dengan baik, sesuai dengan tujuan yang hendak dicapai.

Pelaksanakan pembinaan pemasyarakatan, perlu didasarkan pada suatu asas yang merupakan pegangan atau pedoman bagi para pembina agar tujuan pembinaan yang dilakukan dapat tercapai dengan baik. ${ }^{106}$ Pembinaan narapidana narkoba oleh lembaga pemasyarakatan diatur dalam pasal 5 Undang-Undang Nomor 12 Tahun

${ }^{105}$ Laurensius Arliman S, Penegakan Hukum dan Kesadaran Masyarakat Kedua (Cet. I: Yogyakarta: Deepublis, 2015). H. 209.

${ }^{106}$ Suhandi, Hak dan Kewajiban Warga binaan Lembaga Pemasyarakatan dalam perspektif Hak Asasi Manusi, perspektif,Vol.15,No.2,April 2010, h.195 
1995 tentang Pemasyarakatan yang menjelaskan tentang asas-asas pembinaan pemasyarakatan meliputi: ${ }^{107}$ Pertama, asas pengayoman, Kedua, asas persamaan perlakuan dan pelayanan, Ketiga, asas pendidikan, Keempat, asas pembimbingan, Kelima, asas penghormatan harkat dan martabat manusia, Keenam, asas kehilangan kemerdekaan, Ketujuh, asas terjaminnya hak untuk tetap berhubungan dengan keluarga dan orang-orang tertentu.

Narkoba merupakan singkatan dari narkotika dan obat berbahaya selain narkoba, istilah lain yang diperkenalkan khususnya oleh Kementerian Kesehatan Republik Indonesia adalah Napza yang merupakan singkatan dari narkotika, psikotropika dan zat adiktif.Semua istilah ini, baik narkoba ataupun napsa, semua mengacu pada sekelompok zat yang umumnya mempunyai resiko kecanduan bagi penggunanya.

Pembinaan narapidana di Lembaga Pemasyarakatan Kelas II A Watampone, terbagi menjadi dua yakni: Pertama, pembinaan kemandirian seperti, bimbingan berupa pelatihan bercocok tanam, dan bimbingan keterampilan seperti membuat kerajinan tangan. Kedua, pembinaan kepribadiaan yang meliputi bimbingan kerohanian atau keagamaan, pendidikan dan berbangsa dan bernegara. ${ }^{108}$

Berdasarkan penelitian dapat diketahui bahwai jumlah narapidana penyalahgunaan narkoba yang ditahan di Lembaga Pemasyarakatan Kelas II A Watampone. pada tahun 2016 sebanyak 138 orang, pada tahun 2017 sebanyak 147 orang, pada tahun 2018 sebanyak 166 orang dan pada tahun 2019 sampai saat ini sebanyak 120orang. Ada sekitar 3 orang yang residivis. ${ }^{109}$

${ }^{107}$ Suhandi, Hak dan Kewajiban Warga binaan Lembaga Pemasyarakatan dalam perspektif Hak Asasi Manusia, h.195

${ }^{108}$ Ashar, Kasubsi Registrasi, Lembaga Pemasyarakatan Kelas II A Watampone, wawancara oleh penulis di Lembaga Pemasyarakatan Kelas II A Watampone, 18 Januari 2019.

${ }^{109}$ Ashar, Kasubsi Registrasi, Lembaga Pemasyarakatan Kelas II A Watampone, wawancara oleh penulis di Lembaga Pemasyarakatan Kelas II A Watampone, 18 Januari 2019. 
Berdasarkan data diatas terlihat bahwa jumlah narapidana penyalahgunaan narkoba semakin meningkat setiap tahunnya. Sementara, masalah yang dihadapi dalam pembinaan narapidana narkoba di Lembaga Pemasyarakatan Kelas II A Watampone yakni keterbatasan fasilitas, seperti ruang pendidikan seadanya, pendidikan yang masih kurang dan kurangnya buku-buku pendidikan. Keterbatasan anggaran seperti kegiatan pembinaan narapidana narkoba membutuhkan biaya yakni dibutuhkan peralatan dan bahan-bahan yang dipakai dalam melakukan pembinaan. Keterbatasan sarana dan prasarana seperti ruangannya yang masih terbatas dan keterbatasan sumber daya manusia seperti jumlah petugas yang tidak sebanding dengan jumlah narapidana narkoba, kualitas petugas juga tidak memadai untuk melakukan pembinaan. Jadi, problem yang paling mendasar yang dihadapi dalam pembinaan narapidana narkoba di Lembaga Pemasyarakatan Kelas II A Watampone yakni keterbatasan fasilitas seperti ruang pendidikan seadanya, pendidikan yang masih kurang dan kurangnya buku-buku pendidikan dan sumber daya manusia yang masih terbatas seperti kurangnnya petugas yang bisa membina narapidana narkoba. ${ }^{110}$

Berkenaan latar belakang di atas, maka penulis tertarik untuk mengkaji lebih jauh tentang peran Lembaga Pemasyarakatan Kelas II A Watampone dalam pembinaan narapidana penyalahgunaan narkoba berdasarkan Undang-Undang Nomor 12 Tahun 1995 tentang pemasyarakatan. Hal ini dilakukan untuk mengetahui peran lembaga pemasyarakatan kelas II A Watampone dalam pembinaan narapidana penyalahgunaan narkoba, apakah pembinaan narapidana penyalahgunaan narkobayang dilakukan di Lembaga Pemasyarakatan Kelas II A Watampone. sudah sesuai dengan ketentuan yang termaktub dalam Undang-Undang Nomor 12 Tahun 1995 tentang pemasyarakatan. Berdasarkan latar belakang diatas, maka dapat diambil rumusan masalah sebagai berikut, Bagaimana peran Lembaga Pemasyarakatan Kelas II A Watampone dalam melakukan pembinaaan narapidana penyalahgunaan narkoba

\footnotetext{
${ }^{110}$ Ashar, Kasubsi Registrasi, Lembaga Pemasyarakatan Kelas II A Watampone, wawancara oleh penulis di Lembaga Pemasyarakatan Kelas II A Watampone., 11 Oktober 2018.
} 
berdasarkanUndang-Undang Nomor 12 Tahun 1995 tentang Pemasyarakatan dan Apakah hambatan-hambatan yang dialami Lembaga Pemasyarakatan Kelas II A Watampone dalam melakukan pembinaan narapidana penyalahgunaan narkoba berdasarkanUndang-Undang Nomor 12 Tahun 1995 tentang Pemasyarakatan.

\section{TINJAUAN PUSTAKA}

Dalam penelitian ini, penulis membutuhkan sumber bacaan dan penelitian sebelumnya yang dapat dijadikan sebagai bahan rujukan dan perbandingan dengan judul skripsi yang akan dikaji oleh peneliti. Sumber bacaan yang dimaksud adalah sumber bacaan yang berupa karya ilmiah yang telah ada sebelumnya dan buku-buku yang memiliki korelasi dengan masalah yang penulis angkat sehingga dapat memberikan gambaran tentang sasaran penelitian yang akan dipaparkan dalam penelitian ini, di antaranya:

Penelitian terdahulu yaitu Hasil penelitian yang ditulis oleh Ricki Aditya Putra pada tahun 2013 Mahasiswa Fakultas Hukum Universitas Muhammadiyah Surakarta yang berjudul Peran Lembaga Pemasyarakatan dalam pembinaan narapidana penyalahgunaan narkotika (Studi Di Lembaga Pemasyarakatan Kelas II A Sragen). Dalam Penelitian ini disimpulkan bahwa dalam pembinaan narapidana penyalahgunaan narkotika yaitu dengan memberikan program terapi dan pelatihan yaitu berupa program terapi untuk ketergantungan Napza berupa Program Rumatan metadone, terapi komplementer dan Tahap Rehabilitasi After Care (Pendidikan) yang meliputi kegiatan Pesantren Terpadu, Kursus Bahasa Inggris dan komputer, serta Kegiatan Kerja. Adapun hambatan-hambatan yang dialami oleh lembaga pemasyarakatan Kelas II A Sragen dalam pembinaan narapidana penyalahgunaan narkotika yaitu kurangnya kurangnya kuantitas dan kualitas petugas lembaga pemasyarakatan, jadi yang membedakan dari penelitian ini yakni calon peneliti membahas mengenai pembinaan narapidana narkoba secara keseluruhan sedangkan 
penelitian di atas lebih mengarah pada pembinaan narkotika dan pola-pola pembinaan narapidana narkotika ${ }^{111}$.

Penelitian yang dilakukan oleh Leni Ainurrohmah pada tahun 2013 mahasiswa Jurusan Ilmu Hukum, Fakultas Syari'ah dan Hukum Universitas Islam Negeri Sunan Kalijaga Yogyakarta dalam bentuk skripsi yang berjudul Pembinaan Bagi Narapidana Pelaku Kejahatan Narkotika Di Lembaga Pemasyarakatan Narkotika Kelas IIA Yogyakarta: Metode pembinaan yang dilakukan di Lembaga Pemasyarakatan Narkotika Kelas IIA Yogyakarta dengan mengacu kepada peraturan perundangundangan tentang pembinaan kebanyakan peraturannya sudah sesuai dengan peraturan-peraturan tentang pembinaan yang ada. Adapun yang tidak sesuai dengan peraturan-peraturan pembinaan itupun dari pihak Lembaga Pemasyarakatan Narkotika memang belum mempunyai wadah atau tempat untuk melaksakannya.Pembinaan Narapidana yang sesuai dengan peraturan pembinaan adalah sebagai berikut Pembinaan Narapidana berdasarkan golongannya; pembinaan ibadah, pembinaan perawatan jasmani dan perawatan rohani; pembinaan pelayanan kesehatanatau makanan, pembinaan keluhan, bahan siaran dan media massa,upah dan premi, kunjungan asimilasi dan cuti, pembebasan bersyarat dan cuti menjelang bebas. ${ }^{112}$ Perbedaan dari penelitian diatas lebih memfokuskan pada pembinaan narkotika secara sempit sedangkan calon peneliti lebih membahas tentang peran lembaga pemasyarakatan dalam pembinaan narkoba secara luas.

111 Ricky Aditya Putra, Peran Lembaga Pemasyarakatan dalam Pembinaan Narapidana Penyalahgunaan Narkotika (Studi di Lembaga Pemasyarakatan Kelas IIA Sragen), Skripsi Program Sarjana Fakultas Syariah Hukum Universitas Muhammadiyah Surakarta, 2013

112 Leni Ainurrohma, Pembinaan Bagi Narapidana Pelaku Kejahatan Narkotika (Studi di Lembaga Pemasyarakatan Narkotika kelas IIA yogyakarta), Skripsi program Sarjana Fakultas Syariah dan Hukum, Universitas Islam Negeri Sunan Kalijaga Yogyakarta, 2013 


\section{METODE PENELITIAN}

Salah satu unsur yang dibutuhkan dalam suatu penelitian ialah metode penelitian. Metode penelitian merupakan suatu sarana pokok dalam pengembangan ilmu pengetahuan dan teknologi serta seni. Oleh karena itu, penelitian bertujuan untuk mengungkapkan kebenaran secara sistematis, metodologis, dan konsisten. ${ }^{113}$ Adapun bagian-bagian dari metode penelitian ini yaitu:

\section{Jenis dan Pendekatan Penelitian}

Jenis penelitian yang digunakan berdasarkan karakteristik masalah yang diteliti, maka jenis penelitian yang digunakan adalah penelitian lapangan (kualitatif) dengan mengumpulkan dan menganalisis data berupa kata-kata (lisan maupun tulisan) dan perbuatan-perbuatan manusia. ${ }^{114}$ Penelitian lapangan bertujuan untuk mendapatkan pemahaman yang mendalam tentang masalah-masalah manusia dan sosial dengan menginterpretasikan bagaimana makna tersebut memengaruhi perilaku mereka, bukan mendeskripsikan bagian permukaan dari suatu realitas seperti yang dilakukan peneliti kuantitatif dengan positivismenya. ${ }^{115}$ Penelitian lapangan ini dimaksudkan untuk mengetahui sejauh mana peran Lembaga Pemasyarakatan Kelas II A Watampone dalam Pembinaan Narapidana penyalahgunaan narkoba.

Pendekatan merupakan proses perbuatan, cara mendekati, usaha dalam rangka aktifitas penelitian untuk mengadakan hubungan dengan orang yang diteliti. ${ }^{116}$ Pendekatan yang digunakan dalam penelitian ini

${ }^{113}$ Zainuddin Ali, Metode Penelitian Hukum, h. 17

${ }^{114}$ Afrizal, Metode Penelitian Kualitatif (Cet.I; Jakarta: Rajawali Pers, 2014), h. 13

${ }^{115}$ Haris Herdiansyah, Wawancara, observasi, dan Focus Groups sebagai instrumen penggalian data kaulitatif, (Cet.1; Jakarta: Rajawali Pers, 2013), h. 17.

${ }^{116}$ Departemen Pendidikan dan Kebudayaan, Kamus Besar Bahasa Indonesia (Cet. VI; Jakarta: Balai Pustaka, 1995), h. 218. 
adalah pendekatan yuridis-empiris yang diawali dengan penelitian normatif atau penelahaan terhadap peraturan perundang-undangan (normatif) yang dilanjutkan dengan observasi yang mendalamuntuk mendapatkan data faktor non-hukum yang terkait dan yang berpengaruh terhadap peraturan perundang-undangan yang diteliti. ${ }^{117}$ Penelitian hukum empiris yaitu pendekatan dengan melihat suatu kenyataan hukum di dalam masyarakat. ${ }^{118}$ Dalam hal ini peran lembaga pemasyarakatan dalam pembinaan narapidana penyalahgunaan narkoba. Penelitian hukum normatif dengan cara mengkaji hukum tertulis yang bersifat mengikat dari segala aspek yang kaitannya dengan pokok bahasa yang diteliti.

2. Lokasi Penelitian

Adapun lokasi pelaksanaan penelitian ini diLembaga Pemasyarakatan Kelas II A Watampone, dengan pertimbangan bahwa lembaga ini memenuhi kriteria untuk mendapatkan gambaran tentang pembinaan narapidana penyalahgunaan narkoba berdasarkan UndangUndang Nomor 12 Tahun 1995 tentang Pemasyarakatan. ${ }^{119}$

3. Data dan Sumber Data

Data adalah segala keterangan (informasi) mengenai segala hal yang berkaitan dengan tujuan penelitian, dengan demikian tidak semua informasi atau keterangan merupakan data. Hanyalah sebagian saja dari informasi, yakni yang berkaitan dengan penelitian. ${ }^{120}$ Adapun data yang digunakan dalam penelitian ini adalah:

${ }^{117}$ Dayanto, Peraturan Perundang-Undangan Di Indonesia:Konsep Teknik Pembentukannya Berbasis Good Legislation, (Cet. I; Yogyakarta: CV Budi Utama,2018) h. 72

${ }^{118}$ Zainuddin Ali, Metode Penelitian Hukum, h. 105

${ }^{119}$ Ashar, Kasubsi Registrasi, Lembaga Pemasyarakatan Kelas II A Watampone., wawancara oleh penulis di Lembaga Pemasyarakatan Kelas II A Watampone., 05 Oktober 2018.

${ }^{120}$ Tatang M. Amirin, Menyusun Rencana Penelitian (Cet. III; Jakarta: PT. Raja Grafindo Persada, 1995), h. 130. 
a. Data primer adalah data yang diperoleh langsung dari sumbernya, baik melalui wawancara, observasi maupun laporan dalam bentuk dokumen tidak resmi yang kemudian diolah oleh peneliti. ${ }^{121}$ Data primer yang digunakan dalam penelitian ini yaitu data yang diperoleh secara langsung dari objek yang diteliti baik pribadi (responden) maupun dari suatu instansi yang mengolah data untuk keperluan penelitian, seperti dengan melakukan wawancara secara langsung dengan pihak-pihak yang berhubungan dengan penelitian yang dilakukan.Adapun data primer yang dimaksud oleh peneliti disini yaitu data yang diperoleh langsung dari Lembaga Pemasyarakatan Kelas II A Watampone.

b. Data sekunder adalah data yang diperoleh dari dokumen-dokumen resmi, buku-buku yang berhubungan dengan objek penelitian, hasil penelitian dalam bentuk laporan, skripsi, tesis, disertasi, dan peraturan perundang-undangan. Data sekunder tersebut, dibagi menjadi tiga.

1) Bahan hukum primer yang mengikat terdiri dari peraturan perundang-undangan yang terikat dengan objek penelitian. Yakni Undang-Undang Nomor 12 Tahun 1995 tentang Pemasyarakatan, Peraturan Pemerintah Nomor 31 Tahun 1999 tentang pembinaan dan pembimbingan warga binaan pemasyarakatan, Undang-Undang No 35 Tahun 2009 tentang Narkotika dan Undang-Undang No 5 Tahun 1997 tentang Psikotropika.

2) Bahan hukum sekunder yang terdiri dari buku-buku dan tulisan-tulisan ilmiah hukum yang terkait dengan objek penelitian.

\footnotetext{
${ }^{121}$ Zainuddin Ali, Metode Penelitian Hukum, h. 106
} 
82 | Jumarni

3) Bahan hukum tersier yaitu petunjuk atau penjelasan mengenai bahan hukum primer atau bahan hukum sekunder yang berasal dari kamus, ensiklopedia, majalah, surat kabar, dan sebagainya. ${ }^{122}$

\section{Instrumen Penelitian}

Instrumen penelitian atau alat pengumpulan data bertujuan untuk menentukan kualitas penelitian, karena itu, alat pengumpulan data harus mendapat penggarapan yang cermat. Instrumen yang digunakan dalam penelitian ini yakni daftar pertanyaan. dan alat tulis untuk memudahkan peneliti dalam melakukan wawancara.

5. Teknik Pengumpulan Data

Dalam mengumpulkan data peneliti menempuh hal-hal sebagai berikut:

a. Studi Dokumen atau Bahan Pustaka

Studi dokumen merupakan langkah awal dari setiap penelitian hukum (baik normatif maupun sosiologis), studi dokumen bagi penelitian hukum meliputi studi bahan-bahan hukum yang terdiri dari bahan hukum primer, bahan hukum skunder, dan bahan hukum tersier. Setiap bahan hukum ini harus diperiksa ulang validitas dan kredibilitasnya. Sebab, hal ini sangat menentukan hasil suatu pnelitian. $^{123}$

b. Interview (wawancara), yaitu melakukan tanya jawab langsung dengan objek penelitian yakni pegawai Lembaga pemasyarakatan (Ashar S.H selaku kasubsi registrasi, Surianto S.H., M.H selaku kasubag bimaswat,Deny Indra Hermawan selaku fungsional umum dan Muh. Baydawi selaku staf bimkamaswat), dan narapidana

${ }^{122}$ Zainuddin Ali, Metode Penelitian Hukum, h. 106

${ }^{123}$ Amiruddin dan Zainal Asikin, Pengantar Metode Penelitian Hukum, h. 68 
narkoba (Anna Famelia S.E, Muliati, Muh. Akbar sutari, Hamrayadi, Zulfadli, Fitriani dan Afriani) dan mencatat hasil tanya jawab tersebut kemudian mengolah datanya. ${ }^{124}$

\section{Teknik Analisis Data}

Setelah data terkumpul selanjutnya ialah mengolah dan menganalisis data. Dalam penelitian ini data akan dianalisis secara deskriptif kualitatif. Data berupa uraian yang diperoleh melalui observasi, wawancara dan dokumentasi kemudian data yang telah dikumpulkan selanjutnya diolah dan dianalisis. Pada awal penelitian kualitatif, umumnya peneliti melakukan studi pre-eliminary yang berfungsi untuk verifikasi dan pembuktian awal bahwa fenomena yang diteliti itu benar-benar ada. Pada studi pre-eliminary, peneliti sudah melakukan wawancara dan lain sebagainya dan hasil dari aktivitas tersebut adalah data.

Pada saat peneliti melakukan pendekatan dan menjalin hubungan dengan subjek penelitian dengan responden penelitian, melakukan observasi, membuat catatan lapangan bahkan ketika berinteraksi dengan lingkungan sosial subjek dan informan, itu semua merupakan proses pengumpulan data yang hasilnya adalah data yang akan diolah. Adapun teknik pengolahan data sebagai berikut:

a. Reduksi Data (data reduction)

Mereduksi data berarti merangkum, memilih hal-hal yang pokok, memfokuskan pada hal-hal yang penting, serta mencari tema dan polanya. Dengan demikian, data yang telah direduksi akan memberikan gambaran yang lebih jelas dan mempermudah peneliti untuk melakukan pengumpulan data selanjutnya. ${ }^{125}$

\footnotetext{
${ }^{124}$ Amiruddin dan Zainal Asikin, Pengantar Metode Penelitian Hukum, h. 68

${ }^{125}$ Sugiyono, Memahami Penelitian Kualitatif (Cet. VIII; Bandung: Alfabeta, 2013), h. 92. 
84 | Jumarni

b. Penyajian data (data display).

Penyajian data dalam penelitian kualitatif dilakukan dengan bentuk uraian singkat, hubungan antara kategori bagan dan sejenisnya. Penyajian data akan memudahkan untuk memahami apa yang terjadi, kemudian merencanakan kerja selanjutnya.

c. Penarikan kesimpulan (conclution drawing/verification).

Kesimpulan awal masih bersifat sementara dan akan berubah bila tidak ditemukan bukti-bukti yang kuat pada tahap pengumpulan selanjutnya, tetapi apabila kesimpulan awal tersebut didukung oleh bukt-bukti yang valid dan konsisten pada pengumpulan data selanjutnya, maka kesimpulan yang dikemukakan merupakan kesimpulan yang kredibel. ${ }^{126}$

\section{HASIL PENELITIAN DAN PEMBAHASAN}

Peran Lembaga Pemasyarakatan Kelas IIAWatampone dalam Melakukan pembinaan narapidana penyalahgunaan narapidana narkoba berdasarkan Undang-Undang No. 12 tahun 1995 tentang Pemasyarakatan

Menurut Muh. Baydawi peran lembaga pemasyarakatan dalam pembinaan narapidana narkoba dalam hal pembinaan pihak lapas sudah menyiapakan tahapan pembinaan berupa pembinaan kepribadian, kemandirian dan tahap rehabilitas.Pembinaan narapidana narkoba dalam keseharian narapidana narkoba di Lembaga Pemasyarakatan Kelas II A Watampone.dalam pembinaannya tidak dibedakan dengan narapidana biasa terkecuali yang mengikuti program rehabilitas di

\footnotetext{
${ }^{126}$ Miles B. Matthew dan Huberman A. Michael, Analisis Data Kualitatif, Alih Bahasa (terjemahan) oleh Tjetjep R. Rohidi ( Jakarta: UI-Press, 1992), h. 16-18.
} 
lembaga pemasyarakatan. Sehingga diharapkan kepada narapidana narkoba yang sudah melakukan tindak pidana tidak lagi berbuat kejahatan dan setelah keluar dari masa hukuman dapat diterima baik oleh masyarakat luar. ${ }^{127}$

Pembinaan narapidana narkoba di Lembaga Pemasyarakatan Kelas II A Watampone. pada dasarnya masih mengacu pada pembinaan narapidana pada umumnya dan Undang-Undang Nomor 12 Tahun 1995 tentang pemasyarakatan, namun dengan begitu kompleknya permasalahan yang di hadapi oleh para narapidana maka dalam pembinaan narapidana narkoba hendaknya dilaksanakan lebih spesifik dan perlu kerja sama dengan pihak instansi secara intensif. ${ }^{128}$

Sistem pemasyarakatan dalam pembinaan narapidana narkoba di Lembaga Pemasyarakatan Kelas II A Watampone.disesuaikan dengan proses dan tahap pembinaan yang telah direncanakan. Adapun tujuan pembinaan adalah untuk membentuk warga binaan pemasyarakatan agar menjadi manusia seutuhnya, menyadari kesalahannya, memperbaiki diri, dan tidak mengulangi tindak pidananya lagi, sehingga diterima kembali di lingkungan masyarakat.Untuk mencapai tujuan tersebut narapidana narkoba diwajibkan untuk mengikuti tahap-tahap pembinaan yang telah ditetapkan di Lembaga Pemasyarakatan Kelas II A Watampone. ${ }^{129}$

\footnotetext{
${ }^{127}$ Muh.Baydawi, staf Bimkemaswat, Lembaga Pemasyarakatan Kelas II A Watampone., wawancara oleh penulis di Lembaga Pemasyarakatan Kelas II A Watampone., 24 juli 2019.

${ }^{128}$ Surianto, Ka. Subsi Bimkamaswat, Lembaga Pemasyarakatan Kelas II A Watampone., wawancara oleh penulis di Lembaga Pemasyarakatan Kelas II A Watampone., 24 Juli 2019.

${ }^{129}$ Surianto, Ka. Subsi Bimkamaswat, Lembaga Pemasyarakatan Kelas II A Watampone., wawancara oleh penulis di Lembaga Pemasyarakatan Kelas II A Watampone., 24 Juli 2019
} 
86 | Jumarni

Pembinaan narapidana narkoba di Lembaga Pemasyarakatan Kelas II A Watampone.dilaksanakan dalam beberapa tahap, yaitu: ${ }^{130}$

1. Tahap awal meliputi Pembinaan kepribadian dan kemandirian yang mempunyai program yaitu:

a. Masa pengenalan lingkungan

Masa pengenalan lingkungan adalah masa awal yang harus di jalani oleh narapidana narkoba setelah mereka masuk di Lembaga Pemasyarakatan Kelas II A Watampone., narapidana menjalani program ini selama 30 hari. Pada masa pengenalan lingkungan ini narapidana akan mendapatkan pembekalan tentang kehidupan di lapas yang mencakup tata tertib dan peraturan, hak, kewajiban dan larangan, sosialisasi program pembinaan, sosialisasi dan blok hunian.

b. Pembinaan intelektual dan wawasan kebangsaan

Pembinaan ini di perlukan agar pengetahuan serta kemampuan berfikir warga binaan menjadi semakin meningat, sehingga dapat menunjang kegiatan-kegiatan positif yang di perlukan selama masa pembinan.Pembinaan intelektual merupakan suatu pembinaan yang di tujukaan untuk meningkatkan pengetahuan dan mengembangkan fungsi intelektual narapidana.

\footnotetext{
${ }^{130}$ Muh.Baydawi, staf Bimkemaswat, Lembaga Pemasyarakatan Kelas II A Watampone., wawancara oleh penulis di Lembaga Pemasyarakatan Kelas II A Watampone., 24 juli 2019.
} 
Kegiatan yang dilakukan antara lainmembaca buku-buku yang ada dan tersedia di Lembaga Pemasyarakatan Kelas II A Watampone. ${ }^{131}$

c. Pembinaan keagamaan

Pembinaan keagamaan bertujuan untuk meningkatkan keimanan dan ketaqwaan terhadap tuhan yang maha Esa, sehingga narapidana dapat menyadari akibaat-akibat dari perbuatan yang salah.Bentuk kegiatan keagamaan di lembaga pamasyarakatan kelas II A Watampone disesuaikan dengan agama masing-masing. Bimbingan agama baik islam maupun kristen yang biasa dilakukan pada pagi hari, shalat berjamaah pada waktu dzuhur di masjid setiap harinya, dan bimbingan baca tuis Al-qur'an dan mendengarkan ceramah agama. ${ }^{132}$

d. Pembinaan jasmani (olahraga)

Pembinaan ini bertujuan untuk menjaga kesehatan dan kebugaran narapiana narkoba sekaligus mengasah bakat-bakat olahraga yang dimiliki oleh para narapidana.Melakukan kegiatankegiatan olahraga seperti senam pagi kesegaran jasmani setiap hari, dan pada waktu sore mereka bermain bola voli, tenis meja dan bulu tangkis. ${ }^{133}$

${ }^{131}$ Surianto, Ka. Subsi Bimkamaswat, Lembaga Pemasyarakatan Kelas II A Watampone., wawancara oleh penulis di Lembaga Pemasyarakatan Kelas II A Watampone., 24 Juli 2019

${ }^{132}$ Surianto, Ka. Subsi Bimkamaswat, Lembaga Pemasyarakatan Kelas II A Watampone., wawancara oleh penulis di Lembaga Pemasyarakatan Kelas II A Watampone., 24 Juli 2019

${ }^{133}$ Surianto, Ka. Subsi Bimkamaswat, Lembaga Pemasyarakatan Kelas II A Watampone., wawancara oleh penulis di Lembaga Pemasyarakatan Kelas II A Watampone., 24 Juli 2019 
e. Pembinaan kesadaran hukum.

Pembinaan ini dilaksanakan dengan memberikan penyuluhan hukum yang bertujuan untuk mencapai kesadaran hukum yang tinggi. ${ }^{134}$

Untuk pembinaan kemandirian di lembaga pemasyarakatan kelaas II A Watampone memiliki program kegiatan yaitu Pembinaan kerja. Pembinaan ini bertujuan untuk keterampilan kepada narapidana agar jika mereka bebas nanti bisa di jadikan mata pencaharian, pembinaan ini dilaksanakan setelah narapidana menjalani masa pidananya dan pembinaan ini juga lebih difokuskan untuk narapidana narkoba, karena narapidana narkoba yang lebih cenderung yang sering membuat kerajinan tangan seperti kegiatan menjahit bosara, kegiatan berupa perbengkelan, pengelasan dan pertukangan.

Disamping pelatihan keterampilan yang di berikan oleh petugas pembina di Lembaga Pemasyarakatan Kelas II A Watampone., bahwa pelatihan yang diberikan berupa kursus pertukangan dan pelatihan berupa kerajinan tangan. Dengan demikian pelatihan yang di berikannya akan berguna bagi narapidana untuk kembali kemasyarakat. Sehingga akan bermanfaat bagi narapidana bagi bekal untuk membentuk manusia narapidana agar menjadi manusia mandiri, yakni manusia yang akan

\footnotetext{
${ }^{134}$ Surianto, Ka. Subsi Bimkamaswat, Lembaga Pemasyarakatan Kelas II A Watampone., wawancara oleh penulis di Lembaga Pemasyarakatan Kelas II A Watampone., 24 Juli 2019
} 
mendapatkan lapangan kerja yang sesuai dengan keterampilan yang mereka peroleh selama di Lembaga Pemasyarakatan Kelas II A Watampone. ${ }^{135}$

Sehubungan dengan itu ada juga kerja sama antara Lembaga Pemasyarakatan Kelas II A Watampone.dengan lembaga swadaya masyarakat (LSM) di harapkan dapat membantu untuk menerima dan menyalurkan tenaga kerja narapidana. Menurut petugas pembinaan, LSM yang saat ini berkunjung di lembaga pemasyarakatan guna memberikan bimbingan keterampilan dan ceramah agama. $^{136}$

Untuk itu program pelatihan tidak sekedar memberikan kesibukan kepada narapidana, tetapi lebih berorientasi pada individualyang menempatkan narapidana sebagai manusia yang tersesat dan mendapatkan pembinaan sesuai dengan pasal 12 Undang-Undang Nomor 12 Tahun 1995 tentang Pemayarakatan.

\section{Tahap Lanjutan}

Pembinaan tahap lanjutan di bidang ini dapat dikatakan juga sebagai pembinaan kehidupan sosial kemasyarakatan, yang bertujuan agar mantan narapidana narkoba dapat mudah di terima kembali oleh lingkungan masyarakatnya dan untuk menghilangkan citra buruk, lembaga pemasyarakatan dan mencegah penolakan masyarakat terhadap

${ }^{135}$ Surianto, Ka. Subsi Bimkamaswat, Lembaga Pemasyarakatan Kelas II A Watampone., wawancara oleh penulis di Lembaga Pemasyarakatan Kelas II A Watampone., 25 Juli 2019

${ }^{136}$ Ashar, Kasubsi Registrasi, Lembaga Pemasyarakatan Kelas II A Watampone., wawancara oleh penulis di Lembaga Pemasyarakatan Kelas II A Watampone., 23 Juli 2019. 
90 | Jumarni

mantan narapidana, maka perlu diadakan asimilasi kedalam lembaga pemasyarakatan berupa kunjungan dari keluarga serta organisasiorganisasi kemasyarakatan. ${ }^{137}$ Dengan adanya asimilasi kedalam lembaga pemasyarakatan maka narapidana narkoba tidak merasa dirinya terasing dari lingkungan masyarakat. Asimilasi kedalam Lembaga Pemasyarakatan Kelas II A Watampone.berupa kunjungan keluarga berlangsung 2 kali seminggu pada jam tertentu selama kurang lebih 15 menit. Dengan adanya kunjungan tersebut, narapidana tidak merasa di lupakan oleh keluarganya dan secara psikologis hal tersebut akan membawa dampak positif pada diri narapidana. Kurangnya perhatian keluarga dapat mengakibatkan narapidana frustasi dan hal itu akan mempersulit pembinaan narapidana. ${ }^{138}$

Perlunya asimilasi bagi narapidana sebelum kembali ke masyarakat, hal itu bermanfaat untuk mencegah kecenderungan pemberian cap penjahat bagi masyarakat dan di tolaknya narapidana narkoba di masyarakat.

3. Tahap akhir

Tahap integrasi, pembinaan tahap akhir ini di laksanakan sejak berakhirnya tahap lanjutan. Integrasi sosial merupakan salah satu proses dan hasil kehidupan sosial yang menjadi alat untuk mencapai tujuan kehidupan bermasyarakat. Integrasi sosial ditandai dengan adanya sama,

${ }^{137}$ Surianto, Ka. Subsi Bimkamaswat, Lembaga Pemasyarakatan Kelas II A Watampone., wawancara oleh penulis di Lembaga Pemasyarakatan Kelas II A Watampone., 24 Juli 2019

${ }^{138}$ Surianto, Ka. Subsi Bimkamaswat, Lembaga Pemasyarakatan Kelas II A Watampone., wawancara oleh penulis di Lembaga Pemasyarakatan Kelas II A Watampone., 24 Juli 2019 
yaitu kerja sama mulai dari individu, keluarga dan lembaga. Integrasi sosial adalah suatu proses menyatukan berbagai kelompok dalam masyarakat.

Tingginya angka kriminalitas merupakan penyebab dominan meningkatnya penghuni Lembaga Pemasyarakatan Kelas II A Watampone.Pada lembaga pemasyarakaatan ini memunculan masalahmasalah baru, dimana daya tampung yang tidak memadai dan sarananya yang masih terbatas.

Menurut Anna Famelia. SE salah satu narapidana yang mengatakan bahwa fasilitas yang ada di lembaga pemasyarakatan memang masih terbatas.Salah satu fasilitas yang dia inginkan seperti kipas angin.

Dalam mencapai tujuan pemasyarakatan yang sasaran utamanya adalah pemulihan hubungan yang retak dengan masyarakat, narapidana narkoba harus dikenalkan dengan masyarakat sehingga tidak boleh diasingkan. Dari program pembinaan narapidana itu tidak hanya sekedar pembinaan mental spritual belaka yang diharapkaan dapat meningatkan kualitas akhlak narapidana, akan tetapi juga di lakukan pembinaan yang sifatnya memberian keterampilan (keahlian). Dengan pembinaan yang demikian itu maka sasaran yang hendak di capai adalah agar setelah narapidana narkoba selesai menjalani piananya dan kembali ke masyarakat keahlian tersebut dapat dijadikan bekal usaha apalagi bagi narapidana yang berlatar belakang tidak mempunyai keahlian sebagai modal kerja. ${ }^{139}$

${ }^{139}$ Surianto, Ka. Subsi Bimkamaswat, Lembaga Pemasyarakatan Kelas II A Watampone., wawancara oleh penulis di Lembaga Pemasyarakatan Kelas II A Watampone., 25 Juli 2019 
92 | Jumarni

Program pembinaan sebagaimana di sebutkan di atas, jika dapat tercapai dengan baik akan sangat bermanfaat sebagai bekal narapidana untuk kembali kemasyarakat dengan harapan tidak mengulangi lagi perbuatan melanggar hukum atau tidak menjadi residivis, tetapi dalam prakteknya untuk melaksanakan program pembinaan seperti di sebutkan di atas bukanlah hal yang mudah.

Pembinaan narapidana narkoba di lembaga pemasyarakatan kelas A Watampone di perlukan dukungan dari berbagai pihak, juga kualitas petugas lembaga pemasyarakatan, partisipasi masyarakat baik dengan mengadakan kerja sama dalam pembinaan maupun dengan sikap menunjukan bersedia menerima keluarga narapidana narkoba yang telah selesai menjalani pidananya terutama anggota keuarga narapidana, petugas pemasyarakatan dan masyarakat. Dukungan fasilitas dan danajuga merupakan faktor yang sangat menentukan tercapainya atau tidaknya program pembinaan yang telah kami programkan. ${ }^{140}$

Menurut Muh Baydawi pembinaan narapidana narkoba di lembaga pemasyarakatan pertama narapidana narkoba dilakukan dengan cara Asesmen untuk menentukan bakat dan keterampilan yang bersangkutan kemudian yang ke dua narapidana narkoba setelah narapidana narkoba di asesmen narapidana ditempatkan pada program pembinaan kemandirian dan kepribadian. ${ }^{141}$

${ }^{140}$ Surianto, Ka. Subsi Bimkamaswat, Lembaga Pemasyarakatan Kelas II A Watampone., wawancara oleh penulis di Lembaga Pemasyarakatan Kelas II A Watampone., 24 Juli 2019.

${ }^{141}$ Muh.Baydawi, staf Bimkemaswat, Lembaga Pemasyarakatan Kelas II A Watampone., wawancara oleh penulis di Lembaga Pemasyarakatan Kelas II A Watampone., 24 juli 2019. 
Dalam rangka menjalankan strategi demand reduction (pengurangan kebutuhan zat narkoba) serta meningkatkan kualitas hidup tahanan dan WBP pecandu, penyalahguna, dan korban penyalahgunaan narkoba sehingga dapat diterima kembali dalam tatanan kehidupan sosial masyarakat diperlukan peningkatan layanan rehabilitasi narkotika.

Rehabilitasi narkotika bagi tahanan dan Waraga binaan di UPT pemasyarakatan merupakan bagian dari proses pembinaan dan perawatan kesehatan. oleh karena itu layanan rehabilitasi narkoba harus terintegrasi dengan layanan pembinaan dan layanan kesehatan yang tersedia di UPT pemasyarakatan. ${ }^{142}$

Tahapan rehabilitasi narapidana narkoba bagi tahanan dan warga binaan pemasyarakatan dilaksanakan melalui tahapan informasi awal, skrining, asesmen rehabilitas, pemberian layanan rehabilitas medis dan rehabilitas social. ${ }^{143}$

a. Informasi awal

Setiap tahanan dan narapidana yang baru masuk ke dalam lembaga pemasyarakatan wajib diberikan informasimengenai penyalahgunaan narkoba dan layanan rehabilitas yang tersedia di lembaga pemasyarakatan tersebut. Informasi awal ini diberikan pada proses mapenaling (masa pengenalan lingkungan) dan satu

${ }^{142}$ Muh.Baydawi, staf Bimkemaswat, Lembaga Pemasyarakatan Kelas II A Watampone., wawancara oleh penulis di Lembaga Pemasyarakatan Kelas II A Watampone., 24 juli 2019.

${ }^{143}$ Muh.Baydawi, staf Bimkemaswat, Lembaga Pemasyarakatan Kelas II A Watampone., wawancara oleh penulis di Lembaga Pemasyarakatan Kelas II A Watampone., 24 juli 2019. 
94 | Jumarni

paket dengan informasi kesehatan dasarlaiinya. Informasi yang diberikan mencakup:

1) Pengenalan dampak buruk narkoba

2) Pengenalan layanan kesehatan dan rehabilitas narkoba yang tersedia

3) Penyakit penyerta akibat penyalahgunaan narkoba

Pemberian informasi dapat diberikan oleh petugas ataupun kader kesehatan dengan metode penyuluhan kelompok maupun penyuluhan individu.Media yang digunakan dapat berupa brosur, lembar balik atau film. ${ }^{144}$

b. $\quad$ Skrining

Skrining dilakukan untuk mengetahui dan mengidentifikasi jenis zat yang digunakan serta tingkat risiko penyalahgunaan narkoba.Pelaksanaan skrining dilakukan oleh dokter perawat atau petugas pemasyarakatan yang telah mendapatkan pelatihan, skrining juga dapat dilakukan tes urine narkoba. Tes urine narkoba dapat dilaksanakan di rangan, seperti blok hunian. Tes urine narkoba yang digunakan minimal mampu mendeteksi macammacam zat yaitu Morfin, Alkohol, Kokain,Ampetamin dan marijuana. $^{145}$

${ }^{144}$ Lembaga Pemasyarakatan Kelas II A Watampone, Petunjuk Pelaksanaan Layanan rehabilitasi Narkoba bagi tahanan dan warga binaan pemasyarakatan, h. 8

${ }^{145}$ Muh.Baydawi, staf Bimkemaswat, Lembaga Pemasyarakatan Kelas II A Watampone., wawancara oleh penulis di Lembaga Pemasyarakatan Kelas II A Watampone., 24 juli 2019. 
Dari kegiatan skrining, didapatkan informasi mengenai tingkat resikopenyalahgunaan narkoba.Tingkat risiko terdiri dari tingkat risiko ringan, sedang dan berat. Keterangangnnya:

1) Tahanan dan warga binaan pemasyarakatan dengan hasil skrining menunjukkan tingkat risiko ringan, diberikan edukasi tentang bahaya dan risiko penyalahgunaan narkoba.

2) Tahanan dan warga binaan pemasyarakatan dengan hasil skrining menunjukkan tingkat risiko sedang, diberikan konseling adiksi, selain konseling adiksi, dapat juga dilakukan asesmen rehabilitas.

3) Tahanan dan warga binaan pemayarakatan hasil skrining menunjukkan tingkat risiko berat, dilakukan asesmen rehabilitas.

c. Asesmen Rehabilitas Narkoba

Asesmen rehabilitas dilakukkan setelah mendapatkan informasi dari hasil skrining.Asesmen rehabilitas merupakan pengumpulan informasi untuk mendapatkan gambaranklinis dan masalah yang lebih mendalam dari tahanan dan warga binaan pemasyarakatan secara komperehensif, baik pada saat memulai, selama menjalani, hingga selesai mengikuti layanan rehabilitas. Pelaksanaan asesmen rehabilitasi bertujuan untuk: ${ }^{146}$

\footnotetext{
${ }^{146}$ Muh.Baydawi, staf Bimkemaswat, Lembaga Pemasyarakatan Kelas II A Watampone., wawancara oleh penulis di Lembaga Pemasyarakatan Kelas II A Watampone., 24 juli 2019.
} 
96 | Jumarni

1) Meningkatkan kesadaran tentang besar dan dalamnya masalah yang dihadapi oleh Tahanan dan warga binaan pemasyarakatan terkait penggunaan narkoba.

2) Mengkaji masalah medis, menggali data dan informasi identitas narapidana dan warga binaan pemasyarakatankeluarganya dan lingkungannya. Semua data tersebutdiperlukan untuk mencarilatarbelakang penyebab terjadinyagangguan penyalahgunaan narkoba pada narapidana dan waarga binaan pemasyarakatan.

3) Menyusun rencana terapi

4) Memberikan umpan balik

Asesmen rehabilitas dilakukan oleh tim asesmen rehabilitas yang sudah mendapatkan pelatihan. Tim asesmen rehabilitas terdiri dari dokter atau psikolog, bertugas untuk membuat asesmen narkoba, dan pembimbing kemasyarakatan, bertugas membuat penelitian kemasyarakatan.Untuk mendukung keberhasilan pemberian layanan rehabilitas narkoba, dilaksanakan kegiatan dan layanan pendukung meliputi; perawatan kesehatan umum, perawatan kesehatan akibat penyalahgunnan narkoba, pembinaan mental dan spiritual, pendidikan dan pelatihan kepribadian dan kemandirian. ${ }^{147}$

\footnotetext{
${ }^{147}$ Lembaga Pemasyarakatan Kelas II A Watampone, Petunjuk Pelaksanaan Layanan rehabilitasi Narkoba bagi tahanan dan warga binaan pemasyarakatan, h. 10 
d. Rahabilitas Medis

Layanan rehabilitas medis diberikan diklinik Rutan, lembaga pemasyarakatan dan Rumah Sakit Umum yang ditunjuk oleh Dirjen pemasyarakatan.Untuk dapat memberikan layanan rehabilitas medis. Tujuan layananan terapi rehabilitas medis bertujuan untuk: ${ }^{148}$

1) Penghentian total penggunaan zat narkoba

2) Pengurangan frekuensi dan keparahan pengguna narkoba

3) Memperbaiki fungsi fisik, psikologi dan fungsi adaptasi social

e. Rehabilitas Sosial

Tempat layanan rehabilitas social diberikan di Lembaga Pemasyarakatan Kelas II A Watampone.yang ditunjuk oleh dirjen pemasyarakatan. Untuk dapat memberikan layanan rehabilitas social, diharapkan lembaga pemasyarakatan memiliki sarana berupa: ${ }^{149}$

1) Blok hunian khusus peserta rehabilitas

2) Ruang khusus untuk untuk kegiatan rehabilitas social

Pelaksanaan rehabilitas sosial dapat mengikutsertakan psikolog, pekerja sosial atau rohaniawan. Catatan: jika lembaga pemasyarakatan tidak memiliki tenaga terlatih, maka dapatbekerja sama dengan instansi seperti Badab Narkotika Nasiaonal kabupaten

\footnotetext{
${ }^{148}$ Lembaga Pemasyarakatan Kelas II A Watampone, Petunjuk Pelaksanaan Layanan rehabilitasi Narkoba bagi tahanan dan warga binaan pemasyarakatan, h. 9 .

${ }^{149}$ Lembaga Pemasyarakatan Kelas II A Watampone, Petunjuk Pelaksanaan Layanan rehabilitasi Narkoba bagi tahanan dan warga binaan pemasyarakatan, h. 9 .
} 
98 | Jumarni

atau Lembaga swadaya masyarakat untuk menyediakan tenaga terlatih layanan rehabilitas.

Layanan rehabilitas sosial yang mutlak tersedia di Lembaga pemasyarakatanyakni: ${ }^{150}$

1) Therapeutic community berbasisi kemasyarakatan

Layanan rehabilitas sosial bagi narapidana pecandu, penyalahgunadan korban penyalahgunaan narkoba menggunakan metode terapi komunitas yang dimodifikasi berdasarkan kebutuhan, yang terdiri dari kegiatan evaluasi fisik dan psikis yang dilaksanakan selama 2 minggu dengan fokus kegiatan pada perubahan perilaku.Tahapan evaluasi fisik dan psikiatrik bertujuan untuk menilai masalahfisik serta masalah gangguan mental dan perilaku untuk dilakukan pelaksanaan terapi simtomatis gejalah putus zat. ${ }^{151}$

2) Program inti

Kegiatan ini dirancang untuk fokus pada pengembangan emosional dan intelektual serta perubahan perilaku warga binaan pemasyarakatan.Tujuannya agar narapidana narkoba dapat kembali melaksanakan fungsi sosial dalam kehidupan masyarakat dengan baik dan bertanggung jawab.Pada kegiatan ini, pecandu dan penyalahguna narkoba mulai

\footnotetext{
${ }^{150}$ Lembaga Pemasyarakatan Kelas II A Watampone.,Petunjuk Pelaksanaan Layanan rehabilitasi Narkoba bagi tahanan dan warga binaan pemasyarakatan, h. 11

${ }^{151}$ Muh.Baydawi, staf Bimkemaswat, Lembaga Pemasyarakatan Kelas II A Watampone., wawancara oleh penulis di Lembaga Pemasyarakatan Kelas II A Watampone., 24 juli 2019.
} 
bergabung dalam komunitas terstruktur yang mempunyai hirarki, group seminar dan konseling kelompok sebagai media pendukung perubahan diri.

3) Konseling keluarga

Dalam mempersiapkan diri untuk kembali ke keluarga, terkadang muncul kebutuhan untuk dilakukan konseling keluarga atau dialog keluarga dengan difasilitasi oleh psikolog atau konselor yang bertujuan untuk memfasilitasi komunikasi di dalam keluarga, menfasilitasi penyelesaian konflik dalam keluarga, menfasilitasi proses diskusi rencana setelah rehabilitasi dan lain sebagainyakarena keluarga juga sebagai faktor penunjang untuk memberikan dukungan bagi narapidana narkoba di lembaga pemasyarakatan.

Untuk lebih memperjelas mengenai narapidana di Lembaga Pemasyarakatan Kelas II A Watampone.berikut merupakan data warga binaan. ${ }^{152}$

Tabel 1.1

Data Jumlah Warga Binaan Lembaga Pemasyarakatan Kelas II A

Watampone.

\begin{tabular}{|c|c|c|}
\hline No & Tahun & Narapidana \\
\hline 1 & 2016 & 207 \\
\hline 2 & 2017 & 251 \\
\hline
\end{tabular}

${ }^{152}$ Deny Indra Hermawan, Fungsional Umum, Lembaga Pemasyarakatan Kelas II A Watampone., wawancara oleh penulis di Lembaga Pemasyarakatan Kelas II A Watampone., 23 Juli 2019. 


\begin{tabular}{|l|l|l|}
\hline 3 & 2018 & 300 \\
\hline 4 & 2019 & 284 \\
\hline
\end{tabular}

Tabel 1.2

Data Narapidana Narkoba

\begin{tabular}{|c|c|c|}
\hline NO & Tahun & Narapidana narkoba \\
\hline 1 & 2016 & 138 \\
\hline 2 & 2017 & 147 \\
\hline 3 & 2018 & 166 \\
\hline 4 & 2019 & 120 \\
\hline
\end{tabular}

Berdasarkan data table di atas bahwa dapat di simpulkan narapidana narkoba di Lembaga Pemasyarakatan Kelas II A Watampone.mengalami peningkatan 3 tahun yakni tahun 2016,2017 dan $2018 .^{153}$

\section{Apakah Hambatan-Hambatan Lembaga Pemasyarakatan Kelas Ii A Watamponedalam Pembinaan Narapidana Penyalahgunaan Narkoba Berdasarkan Undang-Undang Nomor 12 Tahun 1995 Tentang Pemasyarakatan}

Lembaga pemasyarakatan berfungsi sebagai tempat pelaksanaan pembinaan narapidana dan anak didik pemasyarakatan.Pembinaan yang dilakukan harus di dasarkan pada bakat, minat serta kebutuhan narapidana, dimana kebutuhan pembinaan bagi narapidana penyalahgunaan narkoba dan narapidana biasa tentunya berbeda karena narapidana narkoba dapat dikatakan telah gagal dalam menerapkan

\footnotetext{
${ }^{153}$ Deny Indra Hermawan, Fungsional Umum, Lembaga Pemasyarakatan Kelas II A Watampone., wawancara oleh penulis di Lembaga Pemasyarakatan Kelas II A Watampone., 23 Juli 2019.
} 
hasil pembinaan di lembaga pemasyarakat.Namun demikian dalam pelaksanaan pembinaan tersebut Lembaga Pemasyarakatan Kelas II A Watampone.menghadapi beberapa faktor yang bisa menghambat berhasilnya pembinaan antara lain belum adanya klasifikasi bagi narapidana narkoba, penempatannya, program-program pembinaan seperti asimilasi dan perbandingan jumlah petugas dengan narapidana yang kurang seimbang, sikap narapidana dalam mengikuti pembinaan, dan kurangnya partisipasi pemerintah dan masyarakat. ${ }^{154}$

Untuk memberantas kejahatan maka pelaku tindak pidana di masukkan ke dalam penjara. Harapannya, pelaku akan memperbaiki diri dan tidak mengulangi tindak kejahatan penyalahgunaan narkoba melalui sistem pembinaan sehingga dapat diterima kembali oleh masyarakat, dan dapat hidup secara wajar sebagai warga yang baik dan bertanggung jawab. Tapi disisi lain, faktanya tingkat kejahatan tidak kunjung menurun. Kejahatan justru semakin merajalela. ${ }^{155}$

Dalam pembinaan narapidana penyalahgunaan narkoba di Lembaga Pemasyarakatan Kelas II A Watampone.terdapat faktor-faktor yang mendapat perhatian karena dapat berfungsi sebagai faktor pendukung dan lebih lagi yang perlu diperhatikan yakni apabila terdapat sebagai faktor yang menjadi kendala. Munculnya hambatan-hambatan tersebut tentunya perlu untuk segera di cari pemecahannya agar dalam proses pembinaan terhadap narapidana dan anak didik pemasyarakatan dapat dilaksanakan dengan baik dan lancar.

${ }^{154}$ Surianto, Ka. Subsi Bimkamaswat, Lembaga Pemasyarakatan Kelas II A Watampone., wawancara oleh penulis di Lembaga Pemasyarakatan Kelas II A Watampone., 24 Juli 2019

${ }^{155}$ Surianto, Ka. Subsi Bimkamaswat, Lembaga Pemasyarakatan Kelas II A Watampone., wawancara oleh penulis di Lembaga Pemasyarakatan Kelas II A Watampone., 24 Juli 2019 
Adapun beberapa hambatan yang berhubungan dengan pembinaan narapidana penyalahgunaan narkoba di Lembaga Pemasyarakatan Kelas II A Watampone.yaitu:

\section{Sarana prasarana}

Keberhasilan lembaga pemasyarakatan narapidana tidak terlepas dari saranaprasarana yang tersedia.Dalam hal ini sarana yang di maksud apakah itu kamar tidur, makanan yang bersih dan sehat, sarana kesehatan dan fasilitas olahraga, semua ini bertujuan untuk mendukung jalannya pembinaan.Oleh karena itu ketersediaan sarana merupakan salah satu ukuran berhasilnya sistem pemasyarakatan.

Adapun sarana prasarana yang menjadi penghambat di lembaga pemasyarakatan kelas II A Watampne adalah kapasitas untuk setiap kamar blok hunian di isi hingga 20 orang dari yang seharusnya 10 orang saja juga kurangnya peralatan atau fasilitas baik dalam jumlah dan mutu, karena dari semuanya itu tidak tertutup kemungkinan faktor tersebut menjadi penyebab tidak aman dan tertibnya keadaan di lembaga pemasyarakatan. ${ }^{156}$

Disamping itu narapidana juga merasakan manfaat sarana yang diperlukan, namun apabila sarana tidak tersedia sangat mungkin menjadi hambatan. Adapun sarana prasarana yang dibutuhkan oleh narapidana di lembaga pemasyarakatan seperti peralatan keterampilan, sarana olahraga, tenaga kesehatan, kamar blok hunian yang layak. Hendaknya sarana dan

\footnotetext{
${ }^{156}$ Ashar, Kasubsi Registrasi, Lembaga Pemasyarakatan Kelas II A Watampone., wawancara oleh penulis di Lembaga Pemasyarakatan Kelas II A Watampone., 23 Juli 2019.
} 
prasarana yang mendukung program pembinaan narapidana narkoba di lembaga pemasyarakatan segera di lengkapi.

2. Sumber daya manusia

Setiap pembinaan narapidana dilembaga pemasyarakatan, bertujuan untuk mempersiapkan narapidana kembali ke masyarakat dengan bekal latihan keterampilan yang diterimanya di lembaga pemasyarakatan.Oleh karena itu peran narapidana, petugas dan masyarakat sangat dibutuhkan agar pembinaan berhasil.Dalam hal ini baik narapidana maupun petugas saling berinteraksi agar program pembinaan dapat berjalan dengan baik.Untuk narapidana dan petugas sebagai sumber daya manusia yang terlibat dalam hal ini harus menyadari peranannya dalam berlangsungnnya pembinaan.

Kondisi yang terjadi di Lembaga Pemasyarakatan Kelas II A Watampone. pola pembinaan bagi narapidana biasa tidak dibedakan dengan pola pembinaan narapidana narkoba atau narapidana lainnya. Di samping jumlah petugas yang tidak sebanding dengan jumlah narapidana, kualitas petugas juga tidak mamadai untuk melakukan pembinaan. ${ }^{157}$

Secara umum, pembinaan narapidana penyalahgunaan narkoba di Lembaga Pemasyarakatan Kelas II A Watampone. tidak berangsung maksimal karena masih minimnya pengetahuan petugas dalam membina narapidana di tambah lagi kurangnya kursus-kursus keterampilan yang diberikan kepada petugas dalam menunjang program pembinaan,

\footnotetext{
${ }^{157}$ Ashar, Kasubsi Registrasi, Lembaga Pemasyarakatan Kelas II A Watampone, wawancara oleh penulis di Lembaga Pemasyarakatan Kelas II A Watampone., 23 Juli 2019.
} 
menyebabkan program pembinaan berangsung seadanya berdasarkan pengetahuan dan pengalaman petugas. Kualitas dan bentuk-bentuk pembinaan tidak semata-mata tidak ditentuan saraana dan fasilitas yang tersedia.Tetapi diperlukan program-program pembinaan yang kreatif serta mudah untuk di lakukan, sehingga dapat berdampak sebagai pembelajaran yang optimal bagi narapidana sebagai bekal keterampilannya untuk kelak setelah keluar dari lembaga pemasyarakatan, maka dari itu hendaknya mengikuti pelatihan yang diadakan khusus bagi petugas agar dapat memberikan materi yang baik pada narapidana.

3. Dana

Dana merupakan fakor yang menunjang untuk melaksanakan pembinaan narapidana, dalam pelaksanaannya maka di butuhkaan peralatan dan bahan-bahan.Sebab program pembinaan tidak hanya satu macam saja sesuai dengan bidang minat maupun pekerjaan atau keterampilan yang mungkin di perlukan untuk kebutuhan dan kepentingan bagi narapidana setelah mereka keluar dari lembaga pemasyarakatan.

Kurang atau tidak adanya dana menjadi salah satu penyebab yang menjadi hambatan dalam pembinaan narapidana, karena dapat mengakibatkan tidak berjalan dan tidak terealisasinya semua program pembinaan bagi narapidana narkoba karena sangat minimnya dana yang tersedia. $^{158}$

\footnotetext{
${ }^{158}$ Deny Indra Hermawan, Fungsional Umum, Lembaga Pemasyarakatan Kelas II A Watampone., wawancara oleh penulis di Lembaga Pemasyarakatan Kelas II A Watampone., 23 Juli 2019.
} 


\section{PENUTUP}

\section{Kesimpulan}

1. Pembinaan narapidana narkoba di Lembaga Pemasyarakatan Kelas II A Watampone. dilaksanakan dalam beberapa tahap, yaitu:

Tahap awal meliputi Pembinaan kepribadian dan kemandirian yang mempunyai program yaitu:

a. Masa pengenalan lingkungan

Masa pengenalan lingkungan adalah masa awal yang harus di jalani oleh narapidana narkoba setelah mereka masuk di Lembaga Pemasyarakatan Kelas II A Watampone., narapidana menjalani program ini selama 30 hari. Pada masa pengenalan lingkungan ini narapidana akan mendapatkan pembekalan tentang kehidupan di lapas yang mencakup tata tertib dan peraturan, hak, kewajiban dan larangan, sosialisasi program pembinaan, sosialisasi dan blok hunian.

b. Pembinaan intelektual dan wawasan kebangsaan

Pembinaan ini di perlukan agar pengetahuan serta kemampuan berfikir warga binaan menjadi semakin meningat, sehingga dapat menunjang kegiatan-kegiatan positif yang di perlukan selama masa pembinan.Pembinaan intelektual merupakan suatu pembinaan yang di tujukaan untuk meningkatkan pengetahuan dan mengembangkan fungsi intelektual narapidana. Kegiatan yang dilakukan antara lain .membacabuku-buku yang ada dan tersedia di Lembaga Pemasyarakatan Kelas II A Watampone.dan Pembinaan keagamaan, pembinaan jasmani, dan pembinaan kesadaran hukum.

Tahap lanjutan yakni pemberian asimilasi ke dalam lembaga pemasyarakatan berupa kunjungan keluuarga pada waktu tertentu 
dan asimilasi keluar lembaga pemasyarakatan dengan member pelatihan pengelasan dan perbengkelan. Sedangkan Tahap akhir tahap integritas dengan mengoptimalkan mengenai pembebasan bersyarat.

Pembinaan narapidana narkoba terkhusus dilakukan pembinaan Rehabilitas.Adapun tahap-tapah pembinaan rehabilitas narapidana narkoba yakni; tahap informasi awal, skinning, Asesmen rehabilitas, rehabilitas medis dan sosial.

2. Adapun hambatan-hambatan Lembaga Pemasyarakatan Kelas II A Watampone.dalampembinaan Narapidana penyalahgunaan narkoba ialah sarana prasarana, sumber daya manusia, dan kurangnya dana. Berdasarkan beberapa hambatan yang dihadapi di Lembaga Pemasyarakat kelas II A Watampone maka penulis berpendapat bahwa pro: pembinaan terhadapa narapidana khususnya narapidana narkoba belı. berjalan maksimal.

\section{DAFTAR REFERENSI}

Ali, Zainuddin. Metode Penelitian Hukum. Cet.V; Jakarta: Sinar Grafika, 2014.

Amirin, Tatang M. Menyusun Rencana Penelitian. Cet. III; Jakarta: PT. Raja Grafindo Persada, 1995.

Amiruddin dan Zainal Asikin, Pengantar Metode Penelitian Hukum, Ed. 1.Cet. II; Jakarta: PT RajaGrafindo Persada, 2004.

Arikunto, Suharsimi. Prosedur Penelitian Suatu Pendekatan Praktik. Cet. XV; Jakarta: Rineka Cipta, 2013.

Arliman S, Laurensius. Penegakan Hukum dan Kesadaran Masyarakat Kedua. Cet. I: Yogyakarta: Deepublis, 2015.

Bungin, Burhan. Analisis Data Penelitian Kualitatif.Cet. II; Jakarta: PT RajaGrafindo Persada, 2003.

Departemen Pendidikan dan Kebudayaan, Kamus Besar Bahasa Indonesia. Cet. VI; Jakarta: Balai Pustaka, 1995. 
Emzir. Metode Penelitian Pendidikan, Kuantitatif dan Kualitatif. Cet. I; Jakarta: Rajawali Pers, 2010.

Lembaga Pemasyarakatan Kelas II A Watampone. Petunjuk Pelaksanaan Layanan rehabilitasi Narkoba bagi tahanan dan warga binaan pemasyarakatan.

Kementrian Agama RI. Al-Fattah Al-Qur'an 20 Baris Terjemahan.

Martono, Lydia Harlinadan SatyaJoewana.Modul Latihan Pemulihan Pecandu Narkoba Berbasisi Masyarakat. Cet I; Jakarta: Balai Pustaka, 2005, h. 34

Matthew, Miles B. dan Huberman A. Michael, Analisis Data Kualitatif. Alih Bahasa (terjemahan) oleh Tjetjep R. Rohidi. Jakarta: UI-Press, 1992.

Narbuko, Cholid dan H. Abu Achmadi, Metodologi Penelitian. Cet. V; Jakarta: Bumi Aksara, 2003.

Peraturan Pemerintah No. 31 Tahun 1999 tentang Pembinaan dan Pembimbingan Warga binaan Pemasyarakatan.

Republik Indonesia. "Undang-Undang Nomor 12 tahun 1995 tentang Pemasyarakatan".

Republik Indonesia. "Undang-Undang Nomor 35 Tahun 2009 tentang Narkotika”.

Ridwan. Belajar Mudah Penelitian untuk Guru, Karyawan dan Penelitian Pemula. Cet. V; Bandung: Alfabeta, 2008.

Riwayadi, Susilo dan Suci Nur Anisya. Kamus Lengkap Bahasa Indonesia. tc; Surabaya: Sinar Terang, th.

Salim HS \& Erlies Septiana Nurbani, Penerapan Teori Hukum pada Penelitian Disertasi dan Tesis(Buku Kedua). Cet. I: Jakarta: PT RajaGrafindo Persada, 2014. h. 141.

Sugiyono. Memahami Penelitian Kualitatif . Cet. VIII; Bandung: Alfabeta, 2013.

Suhandi. Hak dan Kewajiban Warga binaan Lembaga Pemasyarakatan dalam perspektif Hak Asasi Manusia, perspektif. Vol.15,No.2,April 2010, h.195

Teguh, Muhammad. Metodologi Penelitian Ekonomi . Cet. II; Jakarta: PT. Raja Grafindo persada, 2001.

Umar,Husen. Metode Penelitian untuk Skripsi dan Tesis Bisnis.Cet. II; Jakarta: RajaGrafindo Persada, 1999.

W.Js. Poerwadarminta, Kamus Umum Bahasa Indonesia. Jakarta: PT Balai Pustaka, 2006. 